\begin{tabular}{|c|l|}
\hline Title & Effective spatial scales for evaluating environmental determinants of population density in Y akushima macaques \\
\hline Author(s) & A getsuma, Naoki; Koda, Ryosuke; T sujino, Riyou; A getsuma Y anagihara, Y oshimi \\
\hline Citation & $\begin{array}{l}\text { A merican Journal of Primatology, 77(2), 152-161 } \\
\text { https://doi.org/L0.1002/jp.22318 }\end{array}$ \\
\hline Issue Date & 2015-02 \\
\hline Doc URL & http://hdl.handle.net/2115/61455 \\
\hline Rights & $\begin{array}{l}\text { This is the peer reviewed version of the following article: [Am. J. Primatol. 77:152-161, 2015.], which has been } \\
\text { published in final form at [DOI: 10.1002/jp.22318]. This article may be used for non-commercial purposes in } \\
\text { accordance with Wiley Terms and Conditions for Self-A rchiving. }\end{array}$ \\
\hline Type & article \\
\hline File Information & \begin{tabular}{l} 
DisturbMonk.pdf \\
\hline
\end{tabular} \\
\hline
\end{tabular}

Instructions for use 
RESEARCH ARTICLE

\title{
Effective Spatial Scales for Evaluating Environmental Determinants of Population Density in Yakushima Macaques
}

\author{
NAOKI AGETSUMA ${ }^{1}$, RYOSUKE KODA², RIYOU TSUJINO ${ }^{3}$, \\ AND YOSHIMI AGETSUMA-YANAGIHARA ${ }^{4}$
}

1 Wakayama Experimental Forest, Hokkaido University, Wakayama, Japan

2 Research Institute of Environment, Agriculture and Fisheries, Osaka Prefecture, Osaka, Japan

3 Center for Natural Environment Education, Nara University of Education, Nara, Japan

4 Hirai 343-1, Kozagawa, Wakayama, Japan

Population densities of wildlife species tend to be correlated with resource productivity of habitats. However, wildlife density has been greatly modified by increasing human influences. For effective conservation, we must first identify the significant factors that affect wildlife density, and then determine the extent of the areas in which the factors should be managed. Here, we propose a protocol that accomplishes these two tasks. The main threats to wildlife are thought to be habitat alteration and hunting, with increases in alien carnivores being a concern that has arisen recently. Here, we examined the effect of these anthropogenic disturbances, as well as natural factors, on the local density of Yakushima macaques (Macaca fuscata yakui). We surveyed macaque densities at 30 sites across their habitat using data from 403 automatic cameras. We quantified the effect of natural vegetation (broadleaved forest, mixed coniferous/broad-leaved forest, etc.), altered vegetation (forestry area and agricultural land), hunting pressure, and density of feral domestic dogs (Canis familiaris). The effect of each vegetation type was analyzed at numerous spatial scales (between 150 and $3,600-\mathrm{m}$ radii from the camera locations) to determine the best scale for explaining macaque density (effective spatial scale). A model-selection procedure (generalized linear mixed model) was used to detect significant factors affecting macaque density. We detected that the most effective spatial scale was $400 \mathrm{~m}$ in radius, a scale that corresponded to group range size of the macaques. At this scale, the amount of broad-leaved forest was selected as a positive factor, whereas mixed forest and forestry area were selected as negative factors for macaque density. This study demonstrated the importance of the simultaneous evaluation of all possible factors of wildlife population density at the appropriate spatial scale.

Key words: agriculture; alien carnivore; forestry; habitat management; hunting pressure; Macaca fuscata yakui 


\section{INTRODUCTION}

Distribution pattern and population density of wildlife tend to correlate with net productivity of habitats [Luck, 2007; Pettorelli et al., 2009]. Productivity is primarily regulated by the natural environment such as types of vegetation specified by climate and geography. However, increasing human activities have modified the distribution and density of wildlife [Baillie et al., 2004; Estrada, 2013]. For wildlife conservation, it is essential to identify natural factors as well as anthropogenic disturbances that significantly affect a species, and then determine the amount of habitat that should be managed. While managing broad ranges generally provides better results, in reality, lack of funds and laborers, restrictive laws, economic activity, and social conventions make it critical to find the smallest area in which management can effectively secure populations. Although the best spatial scale should logically match the scale at which factors show the greatest effects on density, a systematic protocol for determining the most effective area has yet to be presented. Here, we present a protocol for detecting factors that significantly affect a species and determining the most effective of area that should be managed.

Many primate populations have been affected by human economic activity [Estrada, 2013]. The International Union for Conservation of Nature (IUCN) listed about a half of all primate species as vulnerable to critically endangered [Vié et al., 2009]. Anthropogenic disturbances modify several aspects of primate ecology including distribution and abundance [Arroyo-Rodriguez et al., 2008; de Thoisy et al., 2005; Hoffman \& O'Riain, 2012; Phoonjampa et al., 2011; Rist et al., 2009; Rovero et al., 2012], species richness [de Thoisy et al., 2005; Kumpel et al., 2008], demography [Dunham et al., 2008; Umapathy et al., 2011], social structure [Erb et al., 2012; Gumert et al., 2013; Umapathy et al., 2011], ranging behavior [Guo et al., 2008; Yamada \& Muroyama, 2010], activity budget [Saj et al., 1999], and dietary composition [LaFleur \& Gould, 2009; McKinney, 2011; Saj et al., 1999; Tesfaye et al., 2013]. One of the main factors that disturb primates is hunting both for food [de Thoisy et al., 2005; Kumpel et al., 2008] and for the control of crop raiding [Mekonnenet al., 2012]. Another main factor is habitat alteration, and many studies have tried to determine which types of alteration cause the most damage. Logging and forest fragmentation tend to decrease population density [Arroyo-Rodriguez et al., 2008; Phoonjampa et al., 2011], alter demography [Dunham et al., 2008; Umapathy et al., 2011], ranging patterns, and diet composition [Bracebridge et al., 2012; Guo et al., 2008]. Transformation from natural forests to artificial coniferous plantations also decreases population density [Hill et al., 1994], and expands range size [Furuichi et al., 1982] as food availability declines. Agricultural fields attract some primate species, changing their activity budgets [Jaman \& Huffman, 2013; Saj et al., 1999] and dietary composition [LaFleur\& Gould, 2009; McKinney, 2011; Saj et al., 1999; Tesfaye et al., 2013]. The attracted primate individuals tend to remain longer near agricultural land [Yamada \& Muroyama, 2010]. In addition, dependency on agricultural crops, which are relatively high quality foods for primates, might result in a high reproductive rate through improvement of nutritional condition [Agriculture, Forestry and Fisheries Research Council et al., 2003]. Thus, primate population density could be elevated in the vicinity of agricultural land. In addition, disruption of primate ecology by alien carnivores has 
become a concern [Brockman et al., 2008; de Oliveira et al., 2008; Gumert et al., 2013].

Thus, primate species have been exposed to various types of anthropogenic disturbances. However, these multiple disturbances, as well as natural factors, have rarely been considered simultaneously [Rist et al., 2009]. If not, weighing the relative importance of each factor becomes impossible. Therefore, analyzing all possible factors at the same time is required. Moreover, because the magnitude of disturbance varies with spatial scale, the spatial range to be analyzed is important when evaluating natural and artificially altered vegetation [Coulon et al., 2008]. Positive factors selected at some spatial scales could be even negative factors at other scales [Anderson et al., 2005]. However, most studies have not paid much attention to spatial scales. Even when they have been taken into account, the scales (buffer sizes) have been fixed in advance by referring to some ecological bases such as the home range size of an individual [Fletcher \& Hutto, 2008; Zweifel-Schielly et al., 2009] or group [Pyritz et al., 2010; Rist et al., 2009]. However, ecologically meaningful scales cannot be determined exactly a priori [Zweifel-Schielly et al., 2009]. The spatial scale at which the factors have the greatest influence on wildlife (effective spatial scale) should be detected as a means to evaluate the factors without missing any significant ones. Therefore, protocols determining effective spatial scales are vital. The effective spatial scale is practically useful because it provides the reasonable spatial scale of the area that should be managed.

The aim of this study was to determine essential natural factors and anthropogenic disturbances on the density of Yakushima macaque (Macaca fuscata yaku1), the macaque subspecies endemic to the island of Yakushima, Japan. The macaque mainly feed on fruits, seeds, and leaves of broad-leaved trees [Agetsuma, 1995a; Hanya et al., 2003]. Here we analyzed the effects of several types of natural vegetation as well as anthropogenic disturbances, i.e. habitat alteration, hunting pressure and alien carnivores on local macaque density, and tested the following predictions: Detected significant factors on macaque density change with spatial scale, and apparent effective spatial scale exists that better explains macaque density (Prediction 1). At the effective spatial scale, macaque density increases with the amount of broad-leaved forest (Prediction 2), and decreases with forestry area (Prediction 3). In addition, agricultural land has a positive effect on macaque density (Prediction 4). Macaque density decreases with hunting pressure (Prediction 5) and with feral dog density (Prediction 6).

\section{METHODS}

All research reported in this study adhered to the legal requirements of Japan (in which the research took place) and to the Principles for the Ethical Treatment of Non-Human Primates given by the American Society of Primatologists.

\section{Study Sites and Subjects}

Yakushima is a circular mountainous island (peak, 1,936 m; area, 503 km²; Fig. 1), located $70 \mathrm{~km}$ south of Kyushu Island, southern Japan $\left(30^{\circ} \mathrm{N}, 130^{\circ} \mathrm{E}\right)$. Approximately 13,000 residents live in approximately 20 villages that are primarily located less than 100 
above sea level (a.s.l.). Agricultural fields including orange orchards, rice paddies, pastures, and artificial facilities lie mainly less than $200 \mathrm{~m}$ a.s.l. Primary and secondary evergreen broad-leaved forests, as well as coniferous plantations (Cryptomeria japonica) exist from the coast to approximately $800 \mathrm{~m}$ a.s.l. The area from approximately 800 to $1,800 \mathrm{~m}$ a.s.l. is dominated by mixed forests including coniferous, evergreen, and deciduous broad-leaved trees. In the subalpine region (above 1,800 m a.s.l.), vegetation comprises shrubs such as rhododendron (Rhododendron yakushimanum) and grasslands of dwarf bamboo (Pseudosasa owatarii). Thus, on this island, natural vegetation forms zones that change with altitude (Fig. 1) [Ohsawa et al., 2006; Tagawa, 1994]. The annual precipitation varies with location and ranges from 2,500 to 8,700 $\mathrm{mm}$ [Environment Agency, 1984]. Along the coast, the annual mean temperature is around $20^{\circ} \mathrm{C}$, which corresponds to the margin between subtropical and warm temperate zones [Tagawa, 1994]. However, above 1,000 $\mathrm{m}$ a.s.l., the climate is much cooler, with snowfall in winter and an annual mean temperature of around $10{ }^{\circ} \mathrm{C}$ [Ohsawa et al., 2006].

The Yakushima macaque (M. fuscata yakui) is one of two subspecies of Japanese macaque. This subspecies is distributed in a single location (endemic to the island of Yakushima) with an area of occupancy less than $500 \mathrm{~km}^{2}$. An empirical study of Japanese macaques has estimated the probability of extinction to be more than $5 \%$ during 100 years for local populations having less than $500 \mathrm{~km}^{2}$ of habitat area [Agetsuma, 2007b]. The IUCN rated the Yakushima macaque as endangered until 2008. They live in most regions of the island from the coast to above 1,600 m a.s.l. [Hanya et al., 2004] and feed primarily on fruits, seeds, fallen seeds, and leaves of broad-leaved trees, and insects and fungi [Agetsuma, 1995a,2001; Hanya et al., 2003]. They form multi-male and multi-female groups ranging from 5 to 57 individuals, with a mean group home range of 57 ha (range: $24-110$ ha, $N=8$ ) [Agetsuma, 1995b; Takasaki, 1981]. Ranges between groups frequently overlap with most areas being used by two or more groups [Maruhashi et al., 1998]. They frequently use the forest floor for moving, feeding, resting, self/social grooming, and other daily behaviors.

Extensive logging on Yakushima and the transformation of broad-leaved forests to coniferous plantations (C. japonica) during the 1960s and 1970s has disturbed much of the macaque habitat. After 1980, macaques often caused severe damage to agricultural crops. Efforts to control the macaque population have been increasing since 1976 [Agetsuma, 2007a]. From 2006 to 2009, the annual number of macaques hunted as pests ranged from 497 to 1,125 (data from Kagoshima Prefecture). Despite the pest-control measure that is concentrated around agricultural land, the amount of crop damage has not been appreciably reduced over the past four decades.

Apart from a small weasel (Mustela itatsi sho), wild carnivores have never naturally inhabited the island [Environment Agency, 1984], and therefore this subspecies of macaque has evolved without a natural predator. However, feral domestic dogs (Canis familiaris) and raccoon dogs (Nyctereutes procyonoides) now inhabit the island [Tsujino \& AgetsumaYanagihara, 2006]. The feral dogs would be a potential predator of the macaques. 


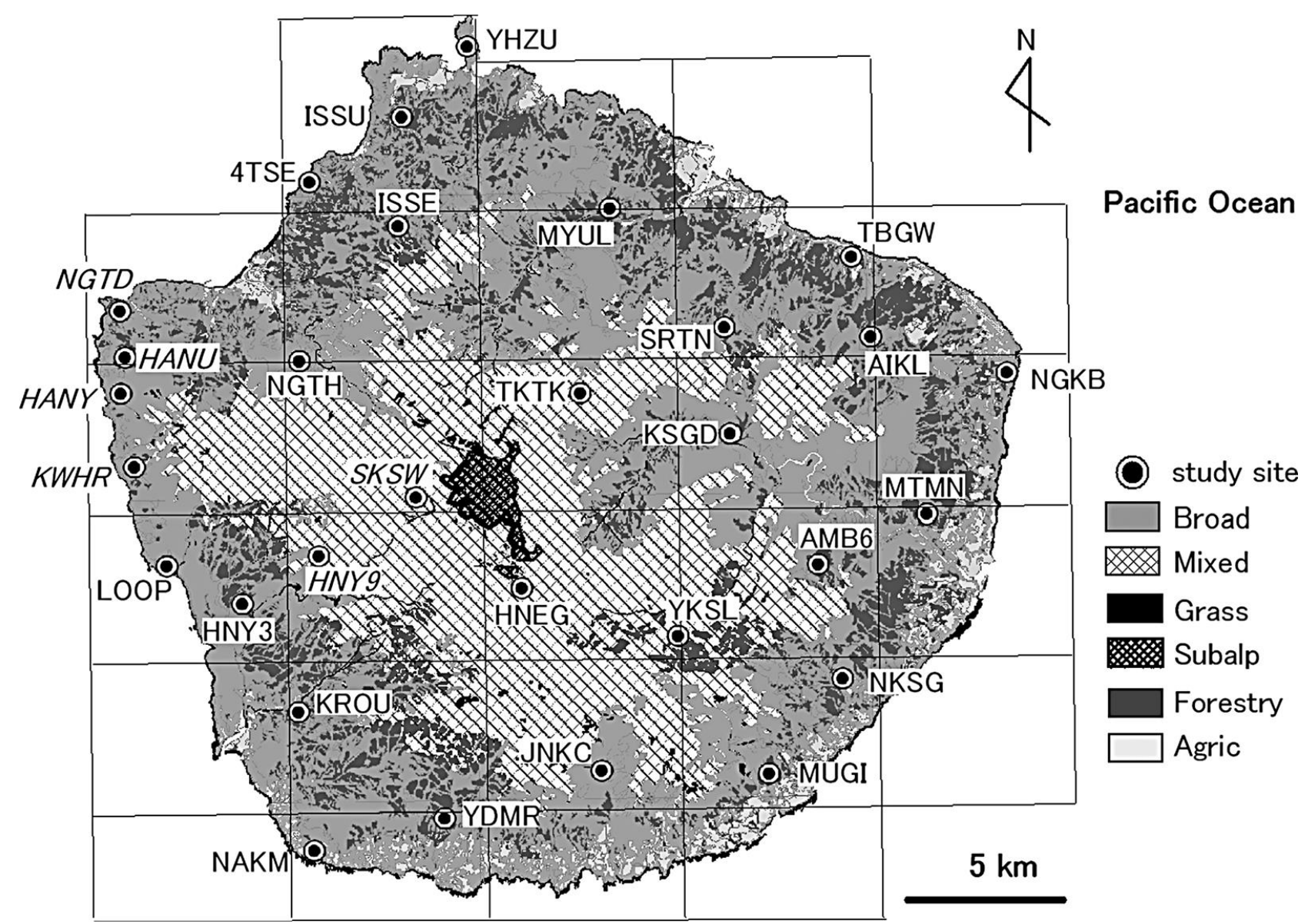

Fig. 1. Vegetation, land use, and study sites on Yakushima. Study site names are expressed by four letters. Italicized six sites were included in the study area of Hanya et al. [2004]. Broad: broad-leaved forest; Mixed: mixed coniferous/broad-leaved forest; Grass: natural grassland; Subalp: subalpine vegetation; Forestry: forestry area; Agric: agricultural land. Natural grassland was distributed very thinly around the coast and rivers. The number of hunted macaques is summarized in approximately $4.6 \mathrm{~km} \times 6 \mathrm{~km}$ cells on the map.

\section{Densities for Macaques and Feral Dogs}

Field surveys were conducted in 30 sites across the island from the coast to 1,700 m a.s.l. (Fig. 1) during periods when snow did not cover the sites from November 2007 to December 2008 intermittently (Table I). The mean minimum-interval between the sites was $2.7 \mathrm{~km}$. We surveyed the densities of mammal species using automatic cameras with infrared sensors that detect animal movement. Such cameras have been used for estimation of relative densities of various mammal species [e.g. Carbone et al., 2002; Rovero \& Marshall, 2009; Rowcliffe et al., 2008]. At each site, about 15 cameras (Yoyshot, Umezawa Musen Denki, Sapporo, Japan) were set up arbitrarily at approximately $100 \mathrm{~m}$ intervals for about one month. We recorded the locations of these cameras with Global Positioning System receivers (GPSmap 60CSx, Garmin, Olathe, Kansas), loaded them with 36 exposures of film, and placed them around $1.4 \mathrm{~m}$ above the ground at a downward angle of approximately $60^{\circ}$ from the ground surface [Okabe \& Agetsuma, 2007]. Each camera covered an area of about $15 \mathrm{~m}^{2}$. The cameras did not function for two minutes after each response of the sensors to avoid consecutive photographing. Because Yakushima macaques use the forest floor for most 
behaviors, we were able to detect their visits to camera locations. The date and time were automatically superimposed on each photograph. Some cameras were damaged by strong winds and heavy rains, but data were obtained from 8 to 15 cameras at each site, totaling 403 cameras (Table I). The mean area of minimum convex polygons surrounding the cameras in each site was 21 ha and the mean maximum width of the polygons was $850 \mathrm{~m}$.

TABLE I Study Site. Study Period. Dav Length. Period of Camera Operation. and Macaque Density Index

\begin{tabular}{|c|c|c|c|c|c|c|c|}
\hline Site & $\begin{array}{l}\text { Mean Alt. } \\
\text { (m) }\end{array}$ & $\begin{array}{c}\text { Month Camera } \\
\text { Set }\end{array}$ & No.Camera ${ }^{b}$ & $\begin{array}{r}\text { Day Length } \\
\text { (hour) }\end{array}$ & $\begin{array}{l}\text { Operating Day }^{d} \\
\text { (24-hour period) }\end{array}$ & $\begin{array}{c}\text { Operating Daytime Period } \\
\text { (12-hour period) }\end{array}$ & Density Index \\
\hline TBGW & 26.7 & May 2008 & 14 & 14.0 & 301.9 & 352.5 & 0.128 \\
\hline NAKM & 40.3 & May 2008 & 13 & 13.9 & 193.3 & 222.6 & 0.140 \\
\hline NGKB & 42.9 & Mar 2008 & 15 & 11.8 & 258.1 & 257.7 & 0.291 \\
\hline YHZU & 43.6 & May 2008 & 8 & 13.9 & 92.5 & 106.1 & 0.370 \\
\hline 4TSE & 68.4 & May 2008 & 14 & 13.9 & 168.4 & 197.8 & 0.112 \\
\hline LOOP & 73.6 & March 2008 & 14 & 11.9 & 146.5 & 146.1 & 0.511 \\
\hline MYUL & 82.5 & November 2007 & 12 & 10.5 & 285.7 & 250.1 & 0.202 \\
\hline$N G T D^{\mathrm{g}}$ & 102.9 & November 2008 & 8 & 10.7 & 161.1 & 144.1 & 0.259 \\
\hline$K W H R^{g}$ & 142.1 & November 2007 & 13 & 10.8 & 187.7 & 166.2 & 0.659 \\
\hline ISSU & 147.5 & February 2008 & 14 & 11.8 & 309.5 & 307.3 & 0.261 \\
\hline HANYg & 168.0 & November 2007 & 15 & 10.7 & 179.0 & 162.1 & 0.362 \\
\hline MTMN & 179.5 & February 2008 & 13 & 11.9 & 292.6 & 291.9 & 0.034 \\
\hline KROU & 183.7 & March 2008 & 14 & 12.0 & 309.2 & 311.9 & 0.128 \\
\hline AIKL & 195.0 & November 2007 & 15 & 10.5 & 347.3 & 304.7 & 0.182 \\
\hline MUGI & 206.9 & March 2008 & 15 & 12.0 & 372.2 & 371.5 & 0.129 \\
\hline NKSG & 290.4 & November 2007 & 14 & 10.6 & 317.9 & 277.5 & 0.431 \\
\hline YDMR & 296.3 & April 2008 & 14 & 13.1 & 382.0 & 416.2 & 0.169 \\
\hline HNY3 & 318.6 & March 2008 & 14 & 12.0 & 289.1 & 290.2 & 0.184 \\
\hline HANUE & 398.2 & November 2008 & 12 & 10.6 & 296.9 & 261.4 & 0.112 \\
\hline NGTH & 452.7 & November 2007 & 15 & 10.7 & 270.7 & 239.8 & 0.313 \\
\hline JNKC & 533.2 & April 2008 & 13 & 13.0 & 272.7 & 297.9 & 0.063 \\
\hline ANB6 & 562.7 & February 2008 & 15 & 11.8 & 342.0 & 337.5 & 0.065 \\
\hline ISSE & 589.5 & November 2007 & 12 & 10.5 & 258.8 & 226.9 & 0.125 \\
\hline SRTN & 642.2 & February 2008 & 15 & 11.7 & 308.9 & 304.1 & 0.024 \\
\hline KSGD & 682.8 & March 2008 & 13 & 12.0 & 347.4 & 347.4 & 0.035 \\
\hline HNYgs & 986.1 & November 2007 & 14 & 10.5 & 425.2 & 368.7 & 0.059 \\
\hline YKSL & 1187.8 & April 2008 & 13 & 13.1 & 366.4 & 402.0 & 0.038 \\
\hline TKTK & 1321.0 & April 2008 & 13 & 13.1 & 290.1 & 318.7 & 0.108 \\
\hline$S K S W$ s & 1589.1 & November 2007 & 14 & 10.6 & 296.1 & 258.9 & 0.092 \\
\hline HNEG & 1650.1 & April 2008 & 15 & 13.0 & 346.2 & 3776 & 0.002 \\
\hline
\end{tabular}

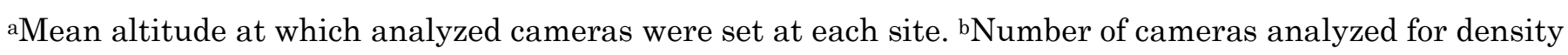
estimation at each site. cMean day length on the intermediate day of operating period of each camera. dTotal number of operating days (24-hour period) of cameras at each site. eTotal number of operating periods in the daytime (12-hour period) of cameras at each site. fMean density index of the macaques (number of macaques photographed per 12-hour of daytime period) at each site. sThe sites included at the study area of Hanya et al. [2004]. 
In addition to identifying the species of photographed animals, we identified individuals by body characteristics (sex, body size, and other physical characteristics), and to prevent repetitive photographing of the same individual during a single visit to a camera, we omitted photographs of the same individuals that were taken within one hour. We then counted the number of macaques and dogs in the photographs. Because cameras were not active throughout the entire study period (through malfunction or completion of the film rolls) we determined the number of hours that each camera was functioning from the dates and times the photographs were taken, and the operating conditions of cameras.

Density index of dogs was determined for each camera by dividing the number of photographed individuals by the number of days (24-hour period) for which the camera operated [Okabe \& Agetsuma, 2007; Rovero \& Marshall, 2009]. Then, the density index was assigned to locations that each camera represented. In Yakushima macaques, time spent foraging and traveling, i.e. active behaviors [Agetsuma, 1995b] which are most likely to be detected by automatic cameras, does not so vary with altitude [Agetsuma, 1995b; Hanya, 2004]. However, total time spent on active behaviors seems to depend on daytime length. The total active behavior was positively correlated with day length (analysis of data shown in Agetsuma and Nakagawa [1998], $r=0.56, N=33, P<0.001$ ). Thus, density index of macaques needed to be calibrated by day length because the periods of camera operation were different (Table I). We summarized operating hours of each camera during daytime of each operating day by referring to time of sunrise and sunset on the intermediate day of the operating period of each camera (data from National Astronomical Observatory of Japan). Then, macaque density index was defined as the number of photographed individuals per 12-hours of daytime.

Hanya et al. [2004] surveyed relative group density and group sizes of the macaques by direct observations from 1993 to 2000 in the western part of Yakushima including six of our study sites (NGTD, HANY, HANU, KWHR, HNY9, SKSW: Fig. 1 and Table I) where hunting and logging were quite limited. They showed that group density was 2.0-2.1 times higher, and group size was 1.4-1.6 times larger, in lower altitude areas (0-400ma.s.1.) than at higher altitudes (>800 $\mathrm{m}$ a.s.1.). Thus, macaque density was apparently higher in the lower altitude areas under natural conditions. To validate the effectiveness of our methods for density estimation [Jennelle et al., 2002], we confirmed whether this tendency was observed in our results.

\section{Hunting Pressure}

During the fiscal years from 2006 to 2008, 1,719 macaques were hunted as pests using shotguns and box traps in Yakushima (data from Kagoshima Prefecture). Kagoshima Prefecture summarized the number of controlled macaques in a systematic grid, comprising cells of approximately $4.6 \mathrm{~km} \times 6 \mathrm{~km}$ (Fig. 1). Because the cells included water surfaces, terrestrial areas in the cells varied. Mean terrestrial areas of the cells were $1,861 \mathrm{ha}(N=27)$. We estimated hunting pressure in each cell by dividing the number of macaques controlled in the cell during the three years by the terrestrial area of the cell. Hunting pressure of each study site corresponded to that of the cell in which the site was located. When the study site 
was located across two cells, we considered the hunting pressure to be the mean hunting pressure of the two cells. The same hunting-pressure value was assigned to each camera within a particular site. Because the spatial resolution of hunting pressure was lower than that of habitat factors, hunting pressure could not be fully evaluated at each spatial scale.

\section{Habitat Factors}

For analyzing habitat factors (natural and altered vegetation), we used data provided by the 6th and 7th National Surveys of the Natural Environment conducted in 2004 by the Biodiversity Center of Japan, Ministry of the Environment. These data were generated by analysis of aerial photographs. Because the minimum width of small patches of land was less than $20 \mathrm{~m}$, the spatial resolution of the data was sufficient for this study. The data were provided in shape files that could be manipulated on a Geographic Information System (GIS: ArcGIS ver. 9.3, ESRI, Redlands, CA). We classified vegetation into six types (Fig. 1): broadleaved forest (mainly evergreen forest), mixed coniferous/broad-leaved forest, natural grassland (mainly riverside and coastal vegetation), subalpine vegetation (dwarf bamboo and rhododendron shrubs), forestry area (coniferous plantations and logged areas), and agricultural land (orchards, rice paddies, pastures, previously arable land, artificial facilities, and human residential areas).

Some climatic factors such as temperature and precipitation might affect macaque density. In Yakushima, variations in altitude result in changing climate, with higher altitudes tending to have lower temperatures, greater precipitation, that shapes vegetation zonation [Ohsawa et al., 2006; Tagawa, 1994]. Therefore, we regarded climatic factors to be reflected in the types of natural vegetation described above.

We created buffer zones within a certain radius from each camera's location on the GIS and calculated the area (ha) of each vegetation type within each buffer zone. We repeated this procedure, changing the radius of the buffer from 150 to $1,800 \mathrm{~m}$ at $50^{-} \mathrm{m}$ intervals and from $1,800 \mathrm{~m}$ to $3,600 \mathrm{~m}$ at $100-\mathrm{m}$ intervals. We used the buffer radii to indicate the spatial scales at which macaque density might be affected by habitat factors.

\section{Detection of Factors that Affected Macaque Density and Determination of the Effective Spatial Scale}

All analyses were performed using the $\mathrm{R}$ statistical computing program, version 3.0.3. [R Core Team, 2014]. We calculated variance inflation factors (VIF) among all eight variables (hunting pressure, dog density at each camera location, and the areas of six types of vegetation around each camera location) at each spatial scale to check for multicollinearity ( $N$ $=403$ ) because data are unreliable if a VIF is greater than 10 [Chatterjee\&Price, 1977]. The VIF of some variables exceeded 10 at many spatial scales. Therefore, we alternately excluded broad-leaved forest and mixed forest area from the variables, and the VIF decreased to less than 3.1 at all spatial scales among the explanatory variables (dog density, hunting pressure, agricultural land, natural grassland, subalpine vegetation, forestry area, and either broadleaved forest or mixed forest). Additionally, absolute values of correlation coefficients between all variables within each variable group at the same spatial scales were less than 0.7 . Thus, 
multicollinearity may be avoided [Dormann et al., 2013] by doing the analysis twice at each spatial scale, once including broad-leaved forest and once with mixed forest in addition to the other six variables. The factors affecting macaque density at each camera location were analyzed with generalized linear mixed models (GLMM) using the "glmmADMB" function in the glmmADMB package of the R. We set the number of photographed macaques in each camera as a response variable, the two groups of variables alternatively as explanatory variables, and the log-transformed amount of operating time of the camera in the daytime (12-hours period) was set as an offset term. Data were collected from multiple cameras at each site, which might have resulted in pseudoreplication [Hurlbert, 1984], this causing spatial autocorrelation of the response variable. For controlling this, the "study site" in which the camera was located was set as a random effect term in the GLMM. We assumed that the response variable follows a negative binomial distribution with a log link function. We performed model selections on the basis of an information theoretic approach [Burnham \& Anderson, 2002] for 192 models with all possible combinations of variables including the null model. We determined the GLMM model having the smallest Akaike's information criteria (AIC) value at each spatial scale using "model.sel" function in the MuMIn package of the $R$. The spatial scale having the smallest AIC model among all spatial scales is the effective spatial scale [Hirao et al., 2008]. At the effective spatial scale, a $95 \%$ confidence set of models was identified by cumulatively summing the Akaike weights in order of highest to lowest until just $\geqq 0.95$ [Burnham \& Anderson, 2002]. For evaluation of variables, we calculated $90 \%$ confidence intervals for each model-averaged coefficient of variable using unconditional standard errors of the coefficient, and relative variable importance according to the sum of the Akaike weights in the $95 \%$ confidence set of models [Burnham \& Anderson, 2002].

\section{RESULTS}

The mean number of cameras used per site for mammal density estimation was 13.4 (total 403 cameras), the mean operating period of each camera was 20.9 days (24-hour period), and the mean operating daytime period (12-hour period) was 20.6 (Table I). We obtained 1,046 images of macaques and 65 of dogs.

There was great variation in mean density index of macaques among sites (Table I). Mean macaque density index of NGTD, HANY, HANU, and KWHR located between 0 and $400 \mathrm{~m}$ a.s.l. was 0.348 and that of HNY9 and SKSW located over $800 \mathrm{~m}$ a.s.l. was 0.075 . This result was similar to that previously reported by Hanya et al. [2004] using different research methods.

Figure 2 shows AIC values of the selected models and selected factors at each spatial scale. Because AIC values roughly reached a plateau at the 3,200-m scale, AIC values up until the 3,600-m scale would be sufficient for examination in this study. Although all factors were selected in any of the spatial scales, the combinations of the selected factors changed largely with spatial scales. 


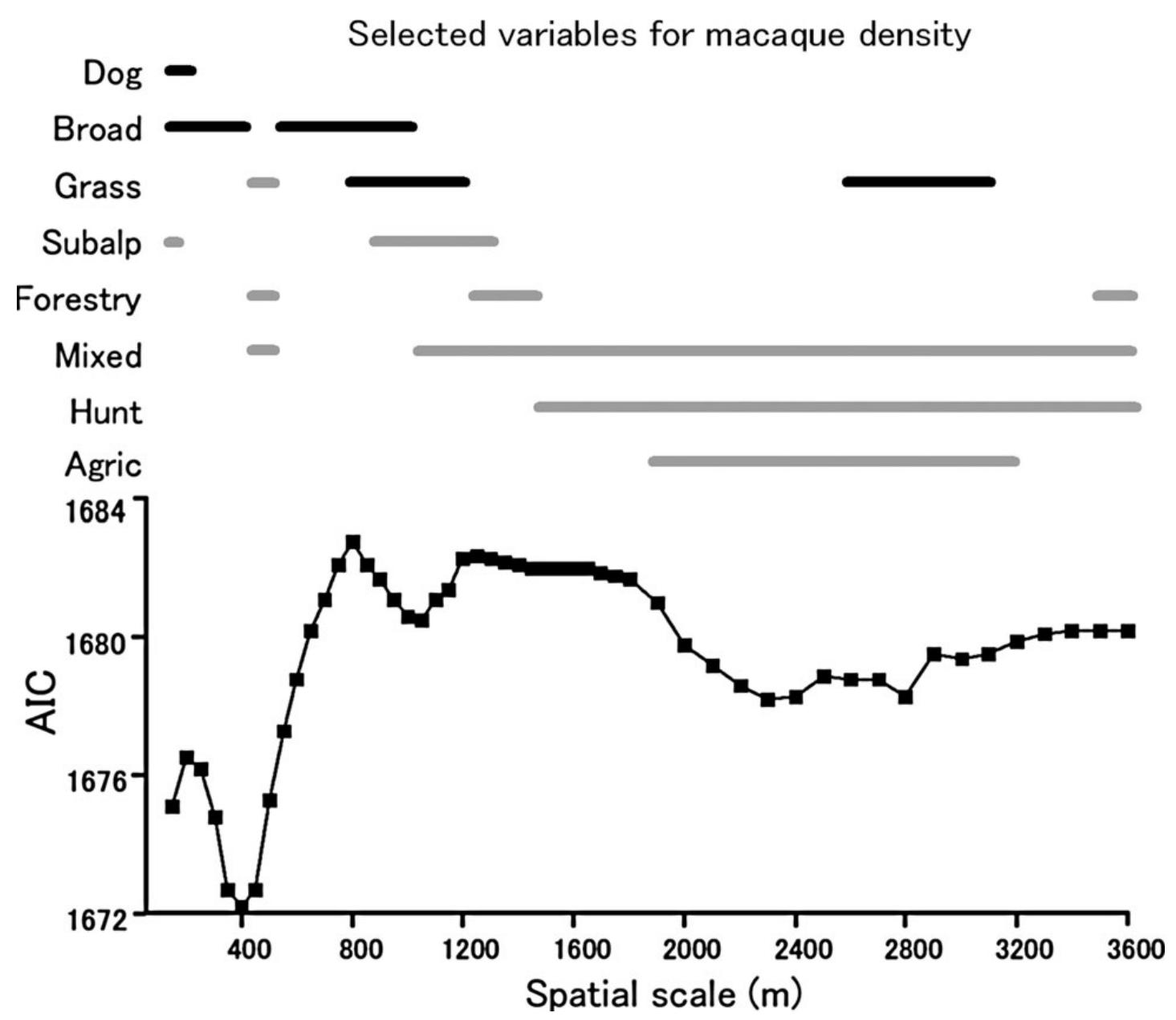

Fig. 2. Selected factors (upper) and Akaike's information criteria (AIC) of the selected models at each spatial scale (lower) for explaining macaque density. Abbreviations of vegetation types are the same as Figure 1. Dog: dog density; Hunt: hunting pressure. Solid and gray lines (upper) indicate positive and negative effects, respectively.

A big dip in AIC values at the $400^{-} \mathrm{m}$ spatial scale indicates that this is the effective spatial scale for habitat factors. The mean buffer area at the 400-m scale (excluding sea and rivers) was 48.1 ha. Only broad-leaved forest was selected in the best model, however other factors were also selected in the equivalent alternative models ( $\triangle \mathrm{AIC}<2.0$ : Burnham and Anderson [2002])(Table II). Akaike weights of these models were not so high and the $95 \%$ confidence set of models consisted of 72 models out of 192 possible models. Figure 3 shows relative variable importance (RVI) and coefficients of each factor at the $400 \mathrm{~m}^{-}$scale. Broadleaved forest had the positive model averaged coefficient with the highest RVI for macaque density. On the other hand, mixed forest had a negative coefficient, however its RVI was relatively low. Forestry area also had a negative coefficient with the second highest RVI, although the $90 \%$ confidence intervals crossed zero slightly. For agricultural land, coefficients among the $95 \%$ confidence set of models ranged from negative to positive values. Model averaged coefficients of hunting pressure and dog density were negative and positive, respectively, however those confidence intervals extensively covered zero.

Around the 2,400-m scale, a shallow dip of AIC appeared, although the $\triangle$ AIC value was around six (Fig. 2). In these special scales, hunting pressure was selected as a negative factor. The mean buffer area of the 2,400-m scale was 1,498.5 ha. 


\begin{tabular}{|c|c|c|c|c|c|c|c|c|c|c|c|c|c|}
\hline Model rank & Intercept & ${ }^{\mathrm{a}}$ Broad & ${ }^{b}$ Mixed & ${ }^{c}$ Forestry & ${ }^{\mathrm{d} A g r i c}$ & ${ }^{e}$ Grass & ${ }^{\mathrm{f} S u b a l p}$ & gHunt & ${ }^{\mathrm{h}}$ Dog & df & AIC & $\triangle \mathrm{AIC}$ & ${ }^{\mathrm{i}} \mathrm{W}$ \\
\hline 1 & -3.28 & 0.041 & & & & & & & & 4 & 1672.2 & 0.00 & 0.056 \\
\hline 2 & -1.17 & & -0.043 & -0.048 & & -0.163 & & & & 6 & 1672.6 & 0.36 & 0.047 \\
\hline 3 & -3.29 & 0.041 & & & & & & & 2.42 & 5 & 1672.8 & 0.58 & 0.042 \\
\hline 4 & -0.99 & & -0.046 & -0.048 & & -0.162 & & -3.88 & & 7 & 1673.3 & 1.10 & 0.033 \\
\hline 5 & -1.19 & & -0.042 & -0.049 & & -0.159 & & & 2.26 & 7 & 1673.4 & 1.15 & 0.032 \\
\hline 6 & -3.20 & 0.043 & & & & & & -2.91 & & 5 & 1673.5 & 1.30 & 0.029 \\
\hline 7 & -3.14 & 0.040 & & -0.010 & & & & & & 5 & 1673.7 & 1.43 & 0.028 \\
\hline 8 & -3.23 & 0.040 & & & & & -0.136 & & & 5 & 1673.8 & 1.58 & 0.026 \\
\hline 9 & -1.16 & & -0.041 & -0.048 & & -0.161 & -0.180 & & & 7 & 1673.8 & 1.58 & 0.026 \\
\hline 10 & -3.32 & 0.042 & & & 0.014 & & & & & 5 & 1674.0 & 1.75 & 0.024 \\
\hline
\end{tabular}

aBroad-leaved forest. ${ }^{b}$ Mixed coniferous/broad-leaved forest. ${ }^{c F o r e s t r y ~ a r e a . ~ d A g r i c u l t u r a l ~ l a n d . ~ e N a t u r a l ~}$

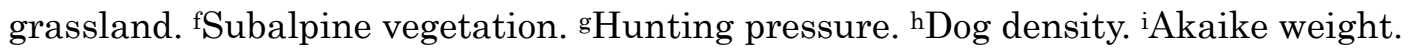

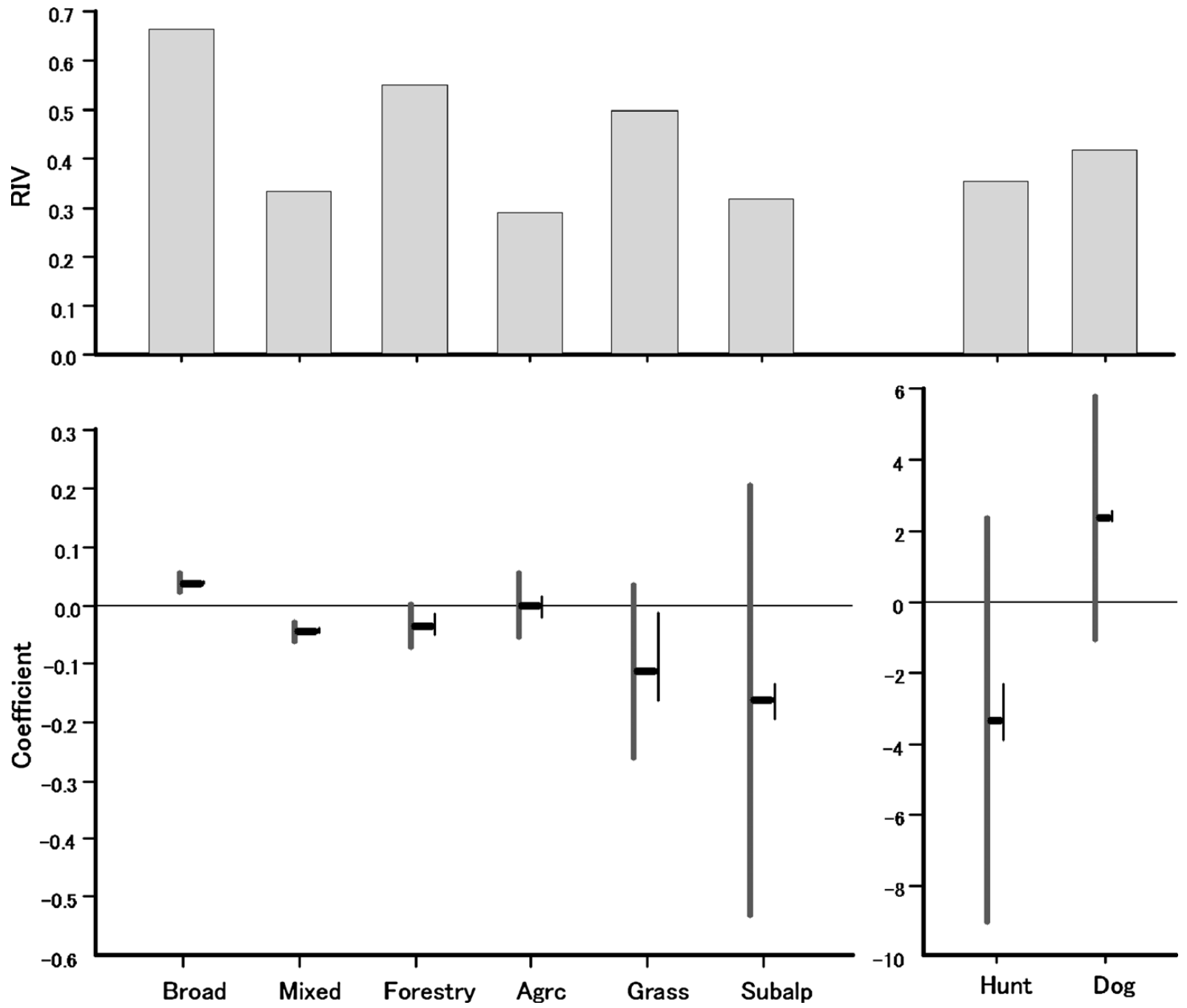

Fig. 3. Relative variable importance (RVI: upper) and coefficient (lower) of each factor. Horizontal lines indicate model averaged coefficients, thick vertical lines (left) indicate the $90 \%$ confident intervals of the coefficients, and thin vertical lines (right) indicate range of coefficients in the $95 \%$ confidence set of models. Abbreviations of factors are the same as Figure 2. 


\section{DISCUSSION}

Combinations of the factors that were selected by our models changed with spatial scale and we were able to extract the distinctive effective spatial scale to better explain local macaque density, thus verifying Prediction 1. This means that unless we evaluate factors at the spatial scales at which they have significant effects on wildlife, we may overlook important factors that should be managed. Effective spatial scales suggest a base of buffer zone width for habitat management.

The effective scale (400-m radius, Fig. 2) contained 48 ha excluding water surfaces. Because the area corresponded to the size of home ranges for the macaques (mean 57 ha) [Agetsuma, 1995b; Takasaki, 1981], they would settle their ranges according to the habitat factors at this scale. At this scale, Prediction 2 appears to be true, and the amount of broadleaved forest was a primary important determinant for macaque density (Fig. 3). In addition, mixed coniferous and broad-leaved forest had a negative effect on macaque density. Forestry area also seemed to decrease macaque density as Prediction 3, although the confidence interval of the coefficient slightly covered zero. These may be because the fruits and seeds that are the most important food for Yakushima macaques are more available in broad-leaved forests than mixed forests [Aiba et al., 2007; Hanya and Aiba, 2010] and coniferous plantations [Hanya et al., 2005].

Contrary to Prediction 4, agricultural land did not have a clear effect on the local density of macaques at the effective spatial scales (Fig. 3). Even if agricultural land attracts macaques, people manage to drive the macaques away from agricultural lands. Moreover, the local government and individual farmers have been constructing electric fences around agricultural land to prevent intrusion by crop-raiding macaques. As a result, agricultural land might have a neutral effect on macaque density.

We could not detect an apparent negative effect of hunting pressure on macaque density at the effective spatial scale (Fig. 3). However, around 2,400-m scales (mean buffer area was 1,498 ha) where AIC values tentatively decreased, hunting pressure was selected as a negative factor (Fig. 2). This may happen because hunting statistics were summarized in ca. a $4.6 \mathrm{~km} \times 6 \mathrm{~km}$ grid system (mean terrestrial area of the cells was 1,861 ha). Impact of hunting pressure may become apparent at a similar spatial scale to the grid system. If hunting pressure could be calculated at much finer spatial scales, a significant impact of hunting pressure might be detected at the effective spatial scale. Nevertheless, in this study, Prediction 5 was not verified. Pest control has been expected to decrease macaque density, thus reducing the amount of damaged crops. Despite the increase in controlled macaques, the amount of crop damage has not decreased over the last four decades in Yakushima [Agetsuma, 2007a]. In terms of adaptive management, ineffective measures should be discontinued in favor of alternative measures [Conservation Measures Partnership, 2007], such as habitat management [Agetsuma, 2007a] and enclosure of agricultural lands with electric fences.

Some studies have reported that alien carnivores are detrimental to primate ecology [Brockman et al., 2008; Gumert et al., 2013]. In Japan, there is anecdotal information that free ranging dogs reduce the population density of wildlife such as Japanese macaques and 
sika deer (Cervus nippon). However, contrary to Prediction 6, we could not detect any negative impact of feral dogs on macaque density (Table II and Fig. 3).

Cercopithecidae species in general tend to show great tolerance and adaptability with regard to habitat alteration [Hoffman \& O'Riain, 2012; Rovero et al., 2012; Tesfaye et al., 2013]. However, Yakushima macaques may have suffered from forestry development. Moreover, transformation of broadleaved forests to other land uses will impact macaque density considerably.

This study demonstrated the importance of simultaneously evaluating all possible factors on wildlife density at the appropriate spatial scales for detecting the significant determinants. The determinants and the effective spatial scale will be useful information for planning wildlife conservation and management.

\section{ACKNOWLEDGEMENTS}

We are grateful to the Ministry of the Environment, the Yakushima Forest Environment Conservation Center, Kagoshima Prefecture, and Yakushima Town for permitting us to conduct this research. WRC of Kyoto University allowed us to use facilities in Yakushima. We would like to thank Drs. T. Mamabe, M. Suzuki, C. Terada, M. Fujita, Mr. K. Iwagawa, and friends in Yakushima for supporting our research, Dr. H. Hirakawa of the Forestry and Forest Products Research Institute for technical support with the automatic cameras, Drs. G. Hanya of Kyoto University and S. Fujita of Kagoshima University for useful information, and two anonymous reviewers for constructive comments on the manuscript.

\section{REFERENCES}

Agetsuma N. 1995a. Dietary selection by Yakushima macaques (Macaca fuscata yakui): the influence of food availability and temperature. International Journal of Primatology 16:611-627.

Agetsuma N. 1995b. Foraging strategies of Yakushima macaques (Macaca fuscata yakui). International Journal of Primatology 16:595-609.

Agetsuma N. 2001. Relation between age-sex classes and dietary selection of wild Japanese monkeys. Ecological Research 16:759-763.

Agetsuma N. 2007a. Ecological function losses caused by monotonous land use induce crop raiding by wildlife on the island of Yakushima, southern Japan. Ecological Research 22:390-402.

Agetsuma N. 2007b. Minimum area required for local populations of Japanese macaques estimated from the relationship between habitat area and population extinction. International Journal of Primatology 28:97-106.

Agetsuma N, Nakagawa N. 1998. Effects of habitat differences on feeding behaviors of Japanese monkeys: comparison between Yakushima and Kinkazan. Primates 39:275-289. Agriculture, Forestry and Fisheries Research Council, Forestry and Forest Products Research Institute, National Agriculture and Bio-oriented Research Organization. 2003. Noringyo 
niokeru yasei jurui no higaitaisaku kisochisiki. Tokyo: Agriculture, Forestry and Fisheries Research Council; Forestry and Forest Products Research Institute; National Agriculture and Bio-oriented Research Organization. 63 p. (in Japanese).

Aiba S, Hanya G, Tsujino R, et al. 2007. Comparative study of additive basal area of conifers in forest ecosystems along elevational gradients. Ecological Research 22:439-450.

Anderson DP, Turner MG, Forester JD, et al. 2005. Scale dependent summer resource selection by reintroduced elk in Wisconsin, USA. Journal of Wildlife Management 69:298310.

Arroyo-Rodriguez V, Mandujano S, Benitez-Malvido J. 2008. Landscape attributes affecting patch occupancy by howler monkeys (Alouatta palliata mexicana) at Los Tuxtlas, Mexico. American Journal of Primatology 70:69-77.

Baillie JEM, Hilton-Taylor C, Stuart SN. 2004. 2004 IUCN red list of threatened species: a global species assessment. Gland, Switzerland and Cambridge, UK: IUCN.

Bracebridge CE, Davenport TR, Marsden SJ. 2012. The impact of forest disturbance on the seasonal foraging ecology of a critically endangered African Primate. Biotropica 44:560568.

Brockman DK, Godfrey LR, Dollar LJ, Ratsirarson J. 2008. Evidence of invasive Felis silvestris predation on Propithecus verreauxi at Beza Mahafaly Special Reserve, Madagascar. International Journal of Primatology 29:135-152.

Burnham KP, Anderson DR. 2002. Model selection and multimodel inference: a practical information-theoretic approach. Second edition. New York: Springer.

Carbone C, Christie S, Conforti K, et al. 2002. The use of photographic rates to estimate densities of cryptic mammals: response to Jennelle et al. Animal Conservation 5:121-123. Chatterjee S, Price B. 1977. Regression analysis by example. New York: John Wiley \& Sons. Conservation Measures Partnership. 2007. Open standards for the practice of conservation, version 2.0. Bethesda, USA: Conservation Measures Partnership.

Coulon A, Morellet N, Goulard M, et al. 2008. Inferring the effects of landscape structure on roe deer (Capreolus capreolus) movements using a step selection function. Landscape Ecology 23:603-614.

de Oliveira VB, Linares AM, Correa GLC, Chiarello AG. 2008. Predation on the black capuchin monkey Cebus nigritus (Primates: Cebidae) by domestic dogs Canis lupus familiaris (Carnivora: Canidae), in the Parque Estadual Serra do Brigadeiro, Minas Gerais, Brazil. Revista Brasileira de Zoologia 25:376-378.

de Thoisy B, Renoux F, Julliot C. 2005. Hunting in northern French Guiana and its impact on primate communities. Oryx 39:149-157.

Dormann CF, Elith J, Bacher S, et al. 2013. Collinearity: a review of methods to deal with it and a simulation study evaluating their performance. Ecography 36:27-46.

Dunham AE, Erhart EM, Overdorff DJ, Wright PC. 2008. Evaluating effects of deforestation, hunting, and El Nino events on a threatened lemur. Biological Conservation 141:287-297. Environment Agency. 1984. Nature of Yakushima. Tokyo: The Nature Conservation Society of Japan. (in Japanese).

ErbWM,Borries C, Lestari NS, Ziegler T. 2012. Demography of simakobu (Simias concolor) 
and the impact of human disturbance. American Journal of Primatology 74:580-590.

Estrada A. 2013. Socioeconomic contexts of primate conservation: population, poverty, global economic demands, and sustainable land use. American Journal of Primatology 75:30-45.

Fletcher RJJ, Hutto RL. 2008. Partitioning the multi-scale effects of human activity on the occurrence of riparian forest birds. Landscape Ecology 23:727-739.

Furuichi T, Takasaki H, Sprague DS. 1982. Winter range utilization of a Japanese macaque troop in a snowy habitat. Folia Primatologica 37:77-94.

Gumert MD, Hamada Y, Malaivijitnond S. 2013. Human activity negatively affects stone toolusing Burmese longtailed macaques Macaca fascicularis aurea in Laem Son National Park, Thailand. Oryx 47:535-543.

Guo ST, Ji WH, Li BG, Li M. 2008. Response of a group of Sichuan snub-nosed monkeys to commercial logging in the Qinling Mountains, China. Conservation Biology 22:1055-1064.

Hanya G. 2004. Seasonal variations in the activity budget of Japanese macaques in the coniferous forest of Yakushima: effects of food and temperature. American Journal of Primatology 63:165-177.

Hanya G, Aiba S. 2010. Fruit fall in five warm- and cool-temperate forests in Yakushima, Japan. Forestry Studies in China 12:184-192.

Hanya G, Noma N, Agetsuma N. 2003. Altitudinal and seasonal variations in the diet of Japanese macaques in Yakushima. Primates 44:51-59.

Hanya G, Yoshihiro S, Zamma K, et al. 2004. Environmental determinants of the altitudinal variations in relative group densities of Japanese macaques on Yakushima. Ecological Research 19:485-493.

Hanya G, Zamma K, Hayaishi S, et al. 2005. Comparisons of food availability and group density of Japanese macaques in primary, naturally regenerated, and plantation forests. American Journal of Primatology 66:245-262.

Hill DA, Agetsuma N, Suzuki S. 1994. Preliminary survey of group density of Macaca fuscata yakui in relation to logging history at seven sites in Yakushima Japan. Primate Research 10:85-93.

Hirao T, Murakami M, Iwamoto J, Takafumi H, Oguma H. 2008. Scale-dependent effects of windthrow disturbance on forest arthropod communities. Ecological Research 23:189-196.

Hoffman TS, O'Riain MJ. 2012. Landscape requirements of a primate population in a humandominated environment. Frontiers in Zoology 9:1.

Hurlbert SH. 1984. Pseudoreplication and the design of ecological field experiments. Ecological Monograph 54:187-211.

Jaman MF, Huffman MA. 2013. The effect of urban and rural habitats and resource type on activity budgets of commensal rhesus macaques (Macaca mulatta) in Bangladesh. Primates 54:49-59.

Jennelle CS, Runge MC, MacKenzie DI. 2002. The use of photographic rates to estimate densities of tigers and other cryptic mammals: a comment on misleading conclusions. Animal Conservation 5:119-120.

Kumpel NF, Milner-Gulland EJ, Rowcliffe JM, Cowlishaw G. 2008. Impact of gun-hunting on diurnal primates in continental Equatorial Guinea. International Journal of Primatology 
29:1065-1082.

LaFleur M, Gould L. 2009. Feeding outside the forest: the importance of crop raiding and an invasive weed in the diet of gallery forest ring-tailed lemurs (Lemur catta) following a cyclone at the Beza Mahafaly Special Reserve, Madagascar. Folia Primatologica 80:233246.

Luck GW. 2007. The relationships between net primary productivity, human population density and species conservation. Journal of Biogeography 34:201-212.

Maruhashi T, Saito C, Agetsuma N. 1998. Home range structure and inter-group competition for land of Japanese macaques in evergreen and deciduous forests. Primates 39:291-301.

McKinney T. 2011. The effects of provisioning and crop-raiding on the diet and foraging activities of human-commensal white-faced capuchins (Cebus capucinus). American Journal of Primatology 73:439-448.

Mekonnen A, Bekele A, Fashing PJ, et al. 2012. Newly discovered Bale monkey populations in forest fragments in southern Ethiopia: evidence of crop raiding, hybridization with Grivets, and other conservation threats. American Journal of Primatology 74:423-432.

Ohsawa M, Tagawa H, Yamagiwa J. 2006. World Heritage, Yakushima. Tokyo: Asakura Publishing. (in Japanese).

Okabe F, Agetsuma N. 2007. Habitat use by introduced raccoons and native raccoon dogs in a deciduous forest of Japan. Journal of Mammalogy 88:1090-1097.

Pettorelli N, Bro-Jorgensen J, Durant SM, Blackburn T, Carbone C. 2009. Energy availability and density estimates in African ungulates. American Naturalist 173:698-704.

Phoonjampa R, Koenig A, Brockelman WY, et al. 2011. Pileated gibbon density in relation to habitat characteristics and post-logging forest recovery. Biotropica 43:619-627.

Pyritz LW, Buntge ABS, Herzog SK, Kessler M. 2010. Effects of habitat structure and fragmentation on diversity and abundance of primates in tropical deciduous forests in Bolivia. International Journal of Primatology 31:796-812.

R Core Team. 2014. R: a language and environment for statistical computing. Vienna: R Foundation for Statistical Computing.

Rist J, Milner-Gulland EJ, Cowlishaw G, Rowcliffe JM. 2009. The importance of hunting and habitat in determining the abundance of tropical forest species in Equatorial Guinea. Biotropica 41:700-710.

Rovero F, Marshall AR. 2009. Camera trapping photographic rate as an index of density in forest ungulates. Journal of Applied Ecology 46:1011-1017.

Rovero F, Mtui AS, Kitegile AS, Nielsen MR. 2012. Hunting or habitat degradation? Decline of primate populations in Udzungwa Mountains, Tanzania: an analysis of threats. Biological Conservation 146:89-96.

Rowcliffe JM, Field J, Turvey ST, Carbone C. 2008. Estimating animal density using camera traps without the need for individual recognition. Journal of Applied Ecology 45:12281236.

Saj T, Sicotte P, Paterson JD. 1999. Influence of human food consumption on the time budget of vervets. International Journal of Primatology 20:977-994.

Tagawa H. 1994. Natural World Heritage, Yakushima. Tokyo: Japan Broadcast Publishing. 
(in Japanese).

Takasaki H. 1981. Troop size, habitat quality, and home range area in Japanese macaques. Behavioral Ecology and Sociobiology 9:277-281.

Tesfaye D, Fashing PJ, Bekele A, Mekonnen A, Atickem A. 2013. Ecological flexibility in Boutourlini's blue monkeys (Cercopithecus mitis boutourlinii) in Jibat forest, Ethiopia: a comparison of habitat use, ranging behavior, and diet in intact and fragmented forest. International Journal of Primatology 34:615-640.

Tsujino R, Agetsuma-Yanagihara Y. 2006. Alien mammals, raccoon dog, feral dog, feral cat, and feral goat in western and north-western part of lowland forest on Yakushima Island in Kagoshima Prefecture. Japanese Journal of Conservation Ecology 11:167-171. (in Japanese).

Umapathy G, Hussain S, Shivaji S. 2011. Impact of habitat fragmentation on the demography of lion-tailed macaque (Macaca silenus) populations in the rainforests of Anamalai Hills, Western Ghats, India. International Journal of Primatology 32:889-900.

Vié J-C, Hilton-Taylor C, Stuart SN, editors. 2009. Wildlife in a changing world: an analysis of the 2008 IUCN red list of threatened species. Gland: IUCN.

Yamada A, Muroyama Y. 2010. Effects of vegetation type on habitat use by crop-raiding Japanese macaques during a food-scarce season. Primates 51:159-166.

Zweifel-Schielly B, Kreuzer M, Ewald KC, Suter W. 2009. Habitat selection by an Alpine ungulate: the significance of forage characteristics varies with scale and season.

Ecography 32:103-113. 